\title{
RBI Distributed Ledger Technology and Blockchain - A Future of Decentralized India
}

\author{
Bhuvana R. ${ }^{1}$ \& P. S Aithal ${ }^{2}$ \\ ${ }^{1}$ Research Scholar, College of Management \& Commerce, Srinivas University, Mangalore, India \\ ${ }^{2}$ Professor, College of Management \& Commerce, Srinivas University, Mangalore, India \\ E-mail: bhuvanareddy08@gmail.com
}

Area/Section: Technology Management.

Type of the Paper:Research Case Study.

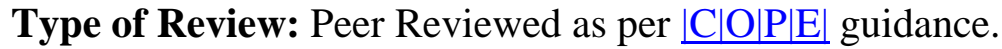

Indexed in: OpenAIRE.

DOI: http://doi.org/10.5281/zenodo.3839780.

Google Scholar Citation:IJMTS.

How to Cite this Paper:

Bhuvana, R. \& Aithal, P. S. (2020). RBI Distributed Ledger Technology and Blockchain - A Future of Decentralized India. International Journal of Management, Technology, and Social Sciences (IJMTS),5(1), 227-237. DOI:http://doi.org/10.5281/zenodo.3839780.

International Journal of Management, Technology, and Social Sciences (IJMTS)

A Refereed International Journal of Srinivas University, India.

(C) With Authors.

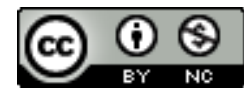

This work is licensed under a Creative Commons Attribution-Non-Commercial 4.0 International License subject to proper citation to the publication source of the work.

Disclaimer: The scholarly papers as reviewed and published by the Srinivas Publications (S.P.), India are the views and opinions of their respective authors and are not the views or opinions of the SP. The SP disclaims of any harm or loss caused due to the published content to any party. 


\title{
RBI Distributed Ledger Technology and Blockchain - A Future of Decentralized India
}

\author{
Bhuvana R. ${ }^{1} \&$ P. S Aithal ${ }^{2}$ \\ ${ }^{1}$ Research Scholar, College of Management \& Commerce, Srinivas University, Mangalore, India \\ ${ }^{2}$ Professor, College of Management \& Commerce, Srinivas University, Mangalore, India \\ E-mail: bhuvanareddy08@gmail.com
}

\begin{abstract}
Despite various countries getting hands-on technology such as blockchain for banking, transaction, and multiple benefits, a developing country such as India must use these technologies because of the advantages it provides in order to keep pace. In the age of digital currencies and new emerging technologies, central banking is a fast-growing topic in the monetary economy. Cryptocurrencies, blockchain, and distributed Ledger technologies appear to be feasible rivals to Fiat Currency central bank. Blockchain technology's influence behind Cryptocurrencies. Cryptocurrencies have the ability to boost payments and operations by central banks and serve as a forum from which central banks could Perhaps launch their own digital currencies. RBI Indian central bank is no less important when it comes to technology that would pave the way for the new economy, enriched with technology-centric growth momentum, by increasing support from India's reserve bank and the Indian government for innovation and integrating technologies through regulatory sandboxes and various other systems. This article illustrates distributed ledger technology in the Indian context. The secondary data were obtained from various scholarly journals and websites. We have analysed distributed ledger technology, India's move towards learning new technologies, different central banks distributed ledger project and examined blockchain technology in the Indian market using the SWOC framework as a research case study.
\end{abstract}

Keywords: FinTech, Distributed Ledger Technology, Reserve Bank of India, IDRBAT, Central Banks, SWOC Analysis.

\section{INTRODUCTION :}

RBI an India's central bank, a regulator of all of India's banks with functions ranging from issuing banknotes to credit control. Founded by British Raj on 1 April 1935. It employs monetary policies to develop financial stability in India and regulates the currency and credit system of the country. Initially, India had various views regarding blockchain and cryptocurrency, primarily because of its decentralized existence. Yet, with a pilot survey on blockchain technology and crypto-currency in different countries.Most central banks have conducted pilot projects to test and appreciate DLT and identify possible benefits for their operations and financial systems. Until now, most of these ventures have been conceptual in nature to investigate the feasibility of conducting interbank transactions, settling digital assets and tokens, and cross-border transfers via DLT networks with existing network functionalities. Many such initiatives, with their consequential benefits, add to the ability of central banks and regulators to guide the development of the DLTbased financial market infrastructure. In the Indian scenario, the focus on digital transactions and increasing support from the Reserve Bank of India and the govt. of India for innovations as well as emerging technologies through regulatory sandboxes and various other schemes would pave the way for a new economy.

FinTech means the convergence of finance, technology and a broad range of services, 
including a wide variety of technological startups that challenge traditional banking and financial players. including crowdfunding platforms for mobile payments. Solutions for online portfolio management tools and international money transfers Fintech products are currently used in international finance, bringing together lenders, borrowers and information providers, with or without a nodal intermediation agency. FinTech attracts interest from both users of banking services and investment funds, who see them as the future of the financial sector. Also, Retail groups and telecommunications operators are also looking for ways to offer financial services through their existing networks [1].DLT and blockchain terms are often used interchangeably. It is important to understand the distinction, however. Blockchain, a linearly linked chain of blocks, is a specific type of DLT, whereas DLT is a decentralized ledger, DLT, as the names imply, is a distribution of a common ledger to all network participants, and it is important to ensure that everyone has the same ledger with particular conditions as well as a procedure for updating the ledger with information related to the ownership of tokens [2]. Central banks may opt to adopt blockchains for use in their payment processing and transaction clearing functions [3]. We have analysed distributed ledger technology, India's move towards learning new technologies, different central banks distributed ledger projects, and examined blockchain technology in the Indian market using SWOC framework as a research case study.

\section{RELATED WORK :}

The associated works of distributed ledger technology were conducted by many researchers while going through the literature from other associated works. Some of the scholarly papers published on distributed ledger technology are listed in Table1 with the contribution of research and references along.

Table 1: Related publications on Distributed Ledger Technology by different researchers.

\begin{tabular}{|l|l|l|}
\hline S.No & Contribution & Reference \\
\hline 1. & $\begin{array}{l}\text { DLT's offer a sovereign digital currency that could be a weapon } \\
\text { for central banks to solve the issue. }\end{array}$ & Smets, J. (2016) [5] \\
\hline 2. & $\begin{array}{l}\text { Central banks have joined the battle, with several signs they are } \\
\text { investigating or experimenting with DLT, and significant focus } \\
\text { is being drawn to the potential of central banks for crypto- or } \\
\text { digital currencies. }\end{array}$ & Bech, M. L., et al. (2017) [6] \\
\hline 3. & $\begin{array}{l}\text { DLT does have the ability that provides new methods of } \\
\text { exchanging and monitoring digital asset possession; stores data } \\
\text { safely; provides for identity management; and other evolving } \\
\text { activities via peer-to-peer networking, connection to a } \\
\text { centralized yet shared participant ledger and cryptography. }\end{array}$ & Mills, D. C., et al. (2016) [7] \\
\hline 4. & $\begin{array}{l}\text { Blockchain's digital currency technology has the ability to } \\
\text { increase central banks' payment and clearing operations and can } \\
\text { be a tool for central banks to launch digital currencies } \\
\text { themselves. }\end{array}$ & Raskin, M., et al. (2018) [3] \\
\hline 5. & $\begin{array}{l}\text { Blockchain is anticipated to revolutionize trade and business and } \\
\text { facilitate world economic transitions because it is immutable, } \\
\text { open, confidence-building that enables safe, fast, reliable and } \\
\text { open solutions, public or private. }\end{array}$ & Guo, Y., et al. (2016) [8] \\
\hline 6. & $\begin{array}{l}\text { This is the time to digitalize the Indian rupee using Blockchain } \\
\text { technology, in order to shift to a cashless society. Fintech and } \\
\text { companies can work closely with governmental agencies } \\
\text { \& policymakers to make sure they promote the use of } \\
\text { Blockchain technology in the phase of law and regulation. }\end{array}$ & \\
\hline
\end{tabular}




\begin{tabular}{|l|l|l|}
\hline 7. & $\begin{array}{l}\text { A number of initiatives have been taken by the government and } \\
\text { private sector to encourage the development of blockchain } \\
\text { technology and industry, public private-partnership has also } \\
\text { been used as instruments for blockchain development. }\end{array}$ & Kshetri, N., et al. (2018) [10] \\
\hline
\end{tabular}

\section{OBJECTIVES OF THE STUDY :}

This study is focused and limited to the analysis of RBI \& central banks Distributed Ledger Technology projects. The main objectives are:

- To exploredistributed ledger technology.

- To identify different central bank projects on distributed ledger technologies.

- To investigate IDBRT suggestions on blockchain technology.

- To determine the classifications and properties of distributed ledger technology.

- To analyse blockchain technology in the Indianmarket using SWOC analysis framework.

- To find what are the possible challenges $\mathrm{RBI}$ is facing in implementing blockchain technology.

\section{RESEARCH METHODOLOGY :}

Secondary data is used for the development of the industrial case study[11]. and for the collection of published data sources. This article describes the distributed ledger technology, India's move towards learning new technologies, different central banks distributed ledger project.

\section{ABOUT DISTRIBUTED LEDGER TECHNOLOGY :}

Distributed ledger technology (DLT) refers to protocols and supporting infrastructure which enables computer systems at various locations to propose and confirm transactions and update documents in a coordinated manner across a network. The idea of a distributed ledger-a shared operating record exchanged across computers at various locations-is not new. Those ledgers are used in a nation or country by businesses (such as supermarket chains) with branches or offices. However, in a typical distributed database, a system administrator generally performs the core functions needed to ensure consistency across several copies of the ledger.

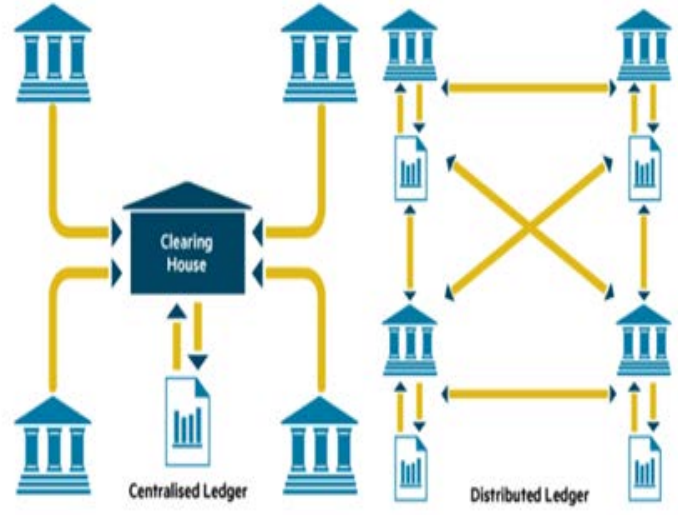

Fig. 1: Representation of centralized and distributed ledgers [6]

\section{BLOCKCHAIN AND DISTRIBUTED TECHNOLOGY IN INDIA AND OTHER CENTRAL BANKS :}

In India, the implementation of $\mathrm{BC}$ and distributed ledger technology Progress was made both within the government and industry in recent times, but the majority of initiatives are being demonstrated. In reality, the government sector is a major consumer of blockchain solutions. Some states like Andhra and Telangana have adopted blockchain technologies in the field of land registry, digital certificates, EHRs. Financial and banking companies are the leading players in the private sector in implementing decentralized technologies. The Central bank of India has also been instrumental in guiding the growth of block chain-based technology via its latest regulatory sandbox program. Blockchain-based start-ups and banks may be included in the regulatory sandbox cohorts for a defined period of time to test their goods. In the 2020-21 Union Budget, the Government of India announced a number of initiatives, concentrated on disruptive technologies such as artificial intelligence, machine learning \& IoT, and more. It proposed a policy allowing the private sector to establish 
data center parks across the country and allocated 6,000 crores to improve grassroots digital connectivity in a five-year period of connecting 1 lakh gram of panchayats to the Bharatnet network with 8,000 crores to the NQTP.

Table 2: DLT projects of different countries central banks

1.Bank of Canada: project jasper

\begin{tabular}{|l|l|l|l|}
\hline S.No & Project objectives & $\begin{array}{l}\text { DLT } \\
\text { Platforms }\end{array}$ & $\begin{array}{l}\text { Published/ } \\
\text { Completed }\end{array}$ \\
\hline 1 & $\begin{array}{l}\text { Build a proof of -concept wholesale interbank payment on } \\
\text { DLT }\end{array}$ & Ethereum & $\begin{array}{l}\text { February } \\
2017\end{array}$ \\
\hline 2 & $\begin{array}{l}\text { Construct extra functionalities like the Liquidity Saving } \\
\text { Mechanism. }\end{array}$ & $\begin{array}{l}\text { Corda } \\
2017\end{array}$ \\
\hline 3 & $\begin{array}{l}\text { Consider examining Delivery versus Payment (DvP) } \\
\text { Security Settlement Solutions }\end{array}$ & Corda & $\begin{array}{l}\text { October } \\
2018\end{array}$ \\
\hline 4 & $\begin{array}{l}\text { Act with the other central banks for using DLT for both the } \\
\text { transnational and cross-currency settlements system }\end{array}$ & $\begin{array}{l}\text { Quorum and } \\
\text { corda }\end{array}$ & May 2019 \\
\hline
\end{tabular}

2.Association of Banks in Singapore and Monetary Authority of Singapore - Project Ubin

\begin{tabular}{|l|l|l|l|}
\hline 1 & POC for making interbank payments using BCT. & Ethereum & March 2017 \\
\hline 2 & $\begin{array}{l}\text { Three specific models of liquidity saving mechanisms for } \\
\text { decentralized interbank payment and settlement. }\end{array}$ & $\begin{array}{l}\text { Quorum, } \\
\text { Hyperledger } \\
\text { Fabric, Corda }\end{array}$ & $\begin{array}{l}\text { November } \\
2017\end{array}$ \\
\hline 3 & $\begin{array}{l}\text { Delivery vs Payment (DvP) capabilities for tokenized asset } \\
\text { settlement across DLT platforms. }\end{array}$ & $\begin{array}{l}\text { Ethereum, } \\
\text { Quorum, } \\
\text { Hyperledger } \\
\text { Fabric, } \\
\text { Chain, } \\
\text { Anquan }\end{array}$ & $\begin{array}{l}\text { November } \\
2018\end{array}$ \\
\hline 4 & $\begin{array}{l}\text { Payment vs cross border payments across Distributed } \\
\text { ledger platforms. }\end{array}$ & $\begin{array}{l}\text { Quorum and } \\
\text { Corda }\end{array}$ & May 2019 \\
\hline 5 & $\begin{array}{l}\text { Enabling broad system collaboration within the same } \\
\text { network for different currencies }\end{array}$ & In progress \\
\hline
\end{tabular}

3.European Central Bank \&Bank of Japan - Project Stella

\begin{tabular}{|l|l|l|l|}
\hline 1 & $\begin{array}{l}\text { Payment systems: methods to preserve liquidity within a } \\
\text { distributed ledger environment }\end{array}$ & $\begin{array}{l}\text { HLFtember } \\
2017\end{array}$ \\
\hline 2 & $\begin{array}{l}\text { Securities settlement systems in a distributed ledger } \\
\text { environment: distribution versus payment. }\end{array}$ & $\begin{array}{l}\text { Elements, } \\
\text { HLF, Corda }\end{array}$ & March 2018 \\
\hline 3 & Payments synchronised around boundaries & HLF & June 2019 \\
\hline
\end{tabular}

4.Bank of Thailand - Project Inthanon

\begin{tabular}{|l|l|l|l|}
\hline 1 & $\begin{array}{l}\text { Constructing Basics: Decentralized interbank settlement } \\
\text { RTGS. }\end{array}$ & Corda & $\begin{array}{l}\text { January } \\
2019\end{array}$ \\
\hline 2 & $\begin{array}{l}\text { Inter-bank repurchase agreement, Bond DvP, Lifecycle of } \\
\text { bond tokens }\end{array}$ & Corda & July 2019 \\
\hline 3 & $\begin{array}{l}\text { Interoperability of cross-border payments with DLT, Corda } \\
\text { collaboration with HKMA's Lionrock project }\end{array}$ & $\begin{array}{l}\text { December } \\
2019\end{array}$ \\
\hline
\end{tabular}




\section{Central Bank of Brazil}

\begin{tabular}{|l|l|l|l|}
\hline 1 & $\begin{array}{l}\text { Listed four use cases and picked, among them, Alternative } \\
\text { Transaction Settlement Method for protyping the principle } \\
\text { proof using it. }\end{array}$ & $\begin{array}{l}\text { Ethereum } \\
2016\end{array}$ \\
\hline 2 & $\begin{array}{l}\text { Improved interbank settlement system characteristics and } \\
\text { evaluated this with competing for blockchain projects }\end{array}$ & $\begin{array}{l}\text { Hyperledger } \\
\text { Fabric, } \\
\text { Corda, } \\
\text { Quorum, }\end{array}$ & March 2017 \\
\hline
\end{tabular}

\section{The South Africa Reserve Bank \&Project Khokha}

\begin{tabular}{|l|l|l|l|}
\hline 1 & $\begin{array}{l}\text { Single Step Construction of an RTGS PoCs on DLT, } \\
\text { expanding privacy and scalability in a 'real' environment. }\end{array}$ & Quorum & June 2018 \\
\hline
\end{tabular}

\section{Bank of England in collaboration with}

\begin{tabular}{|l|l|l|l|}
\hline 1 & $\begin{array}{l}\text { PwC - Evaluate the potential of DLT, achieve in-house } \\
\text { capacities \& knowledge in PoC use case of transfer of } \\
\text { ownership between several participants of a fictional asset. }\end{array}$ & 2016 \\
\hline 2 & $\begin{array}{l}\text { Ripple-PoC to exploring synchronized movements in two } \\
\text { different Real Time Gross Settlement (RTGS) systems, in } \\
\text { two different simulated currencies. }\end{array}$ & $\begin{array}{l}\text { Interledger } \\
\text { Protocol }\end{array}$ & July 2017 \\
\hline 3 & $\begin{array}{l}\text { Clearmatics Technologies Ltd, Baton Systems, R3 and } \\
\text { Token - Poc to understand how renewed RTGS services in } \\
\text { networks using advanced payment technologies such as } \\
\text { DLT can help settlements. }\end{array}$ & Corda 2018 \\
\hline
\end{tabular}

\section{Source: RBI bulletin February 2020}

\section{CLASSIFICATION OF DLT AND PROPERTIES :}

Blockchain technology can first be used in a wide range of different applications and sectors independently, ranging from banking to the healthcare sectors. In almost every sector where properties are managed and transactions are carried out a blockchain can be applied. Thanks to its features, which permit transactions through trust, consensus, protection and intelligent contracts, it can provide a stable custody chain for both the digital and physical properties.

\subsection{PUBLIC AND PRIVATE} BLOCKCHAINS :

Blockchains may be categorized according to their application as public, private or hybrid and consortium variants:

(1) Public: Public blockchains do not have a single owner; they are perfect for everybody; they are available for all and are completely decentralized. Bitcoin is an instance of a public blockchain.

(2) Private: (private blockchains are also known as permitted) use access rights to the blockchain readers and writers. Consensus and mining algorithms are usually not required because a single entity owns and controls block production.

(3) Hybrid: Such BC are also classified as a consortium, and only a limited group has public access. The consensus process is verified by established, privileged servers which use a set of rules agreed upon by all parties. Only qualifying participants shall have copies of the blockchain; hence the network is only partially decentralized.

\subsection{PROPERTIES :}

(1) Distributed: DLT's distributed nature allows nodes to be scaled over a DLT network. Thus, the ability of a bad actor to affect the consensus protocol used by the DLT is minimized by increasing the number of nodes, making it more immune to bad actor attacks.

(2) Consensus Driven:(Trust verification) Each block on the blockchain is independently validated via Consensus models which provide rules for the validation of the block and often 
use a scarce resource (such as computing power) to demonstrate sufficient effort. In Bitcoin, this is called the mining process. This mechanism operates without the use of a central authority or an explicit trust-provider.

(3) Transparent: Since the blockchain is an open file (full transaction history), every party can access it and inspect transactions. It provides provenance under which you can track asset lifetimes.

(4) Append only: A full transactional history is given by an append only ledger. Like standard databases, a DLT does not delete transactions and values.

(5) Immutable: Distributed ledgers are cryptographically protected and permanent, meaning that the data in the ledger is not changed and that the data in the ledger is attestable.

(6) Shared: The ledger is shared between multiple nodes. Some nodes contain the full ledger status while others do not necessarily contain the full ledger status. This gives the node participants in the DLT network transparency and optimum performance.

(7) Digital: Everything of the blockchain information is. Digitized, removing the need to log manually.

(8) Consensus based:A transaction on the blockchain can only be performed if it is secretly accepted by all parties on the network. Consensus based rules can, however, be modified to match various circumstances.

(9) Chronological and timestamp:As the name suggests, blockchain is a chain of blocks, each of which is respiratory storage of information. With respect to a transaction, and also ties in the same transaction to the previous blocks. Such linked blocks from the sequential chain that include or check the transaction that underlies it. (10) Cryptographically sealed: Blocks in a chain are cryptographically locked. That means deleting is impossible. Change blocks already created for copyright and put them there on the network. By creating true digital properties, and maintaining Robustness \& Trust's eye level.

\section{THE IDRBTSUGGESTION ON BCT OF THE INDIAN BANKING SYSTEM :}

The IDRBT was founded by the Reserve Bank of India in 1996, an autonomous center for banking technology development and research. IDRBT has been developed as the backbone of touch for the Indian banking and financial sectors, the Indian Financial Network (INFINET). INFINET, the Structured Financial Messaging (SFMS) Systems, MIS, EFT, ECS, Electronic Debiting, Online Trading and Trades of Government Securities, Centralized Funds Demanding Banks and Financial Institutions and Anywhere / Anytime banking and Inter-bank Reconciliation, are a range of interbank and intra-bank applications [12,13].

(1) Intra-bank usage of BCT :

For their internal purpose's banks can set up a private blockchain. This not only allows them to train the technology's human capital but also to benefit from effective asset management, crossselling opportunities.

(2) Inter-bank usage of BCT :

In the following sequence of that complexity of the implementation, the implementation and validation of the proof of concept can be carried out primarily on account of the number of stakeholders in the transaction.

TABLE 3 :The stages of the phased approach of BCT

\begin{tabular}{|l|l|l|}
\hline S.No & Application & Usage \\
\hline 1 & Centralized KYC & $\begin{array}{l}\text { Safe, distributed customer information databases shared between } \\
\text { organizations help reduce duplicative onboarding efforts. Safe } \\
\text { codification of account information will allow for greater } \\
\text { transparency and transaction tracking efficiency. }\end{array}$ \\
\hline 2 & $\begin{array}{l}\text { Cross-Border } \\
\text { Payments }\end{array}$ & $\begin{array}{l}\text { BCT allows settlement in real time and reduces liquidity and } \\
\text { operational costs Transparent unchanging BCT knowledge } \\
\text { eliminates fraudulent transactions. Due to a reduction of overall costs, } \\
\text { BCT allows reciprocal contact between sender and beneficiary banks } \\
\text { and low value transactions. }\end{array}$ \\
\hline
\end{tabular}




\begin{tabular}{|l|l|l|}
\hline 3 & Syndication of loan & $\begin{array}{l}\text { Automated underwriting operations and financial details in the } \\
\text { distributed header can be used. KYC parameters can also be } \\
\text { implemented in real time automatically. BCT can provide a global } \\
\text { cost saving potential in project execution and settlement subprocesses } \\
\text { of syndicated loans. }\end{array}$ \\
\hline 4 & Trade finance & $\begin{array}{l}\text { The use of BCT in trade financing provides LC with the automation, } \\
\text { payment of paperwork, innovations in real time software and cost } \\
\text { savings associated with the introduction of AML and customs } \\
\text { operations. }\end{array}$ \\
\hline 5 & Capital markets & $\begin{array}{l}\text { BCT has the advantages to minimize or remove product defects, } \\
\text { streamline the operations of the office and slash settlement times in } \\
\text { clearing and settlement procedures. }\end{array}$ \\
\hline
\end{tabular}

9. SWOC ANALYSIS OF BLOCKCHAIN TECHNOLOGY IN INDIAN MARKET :

In this section, the strengths, weaknesses, opportunities and challenges of Blockchain technology in Indian market SWOC analysis

Table 4: The SWOC Analysis of blockchain technology in the Indian market identifies its [14], [15], [16]. Table 4 lists Blockchain technology strengths, weaknesses, opportunities, and challenges with specific reference to the Indian market.

\begin{tabular}{|c|c|}
\hline Constructs & Features \\
\hline Strengths & $\begin{array}{l}\text { - Blockchain solves phone spam issues with India's telecommunications authority } \\
\text { implementing blockchain. This allows only registered users to participate in } \\
\text { telemarketing by reducing telephone spamming and enabling the correct } \\
\text { agencies to monitor and locate. } \\
\text { - Kerala is the first state to offer blockchain more significance by being a working } \\
\text { Kerala start-up mission entered GITEX Technology Week in Dubai World } \\
\text { Trade Centre\& according to linden research, India is expected to have the } \\
\text { largest blockchain market in } 2020 \text {. } \\
\text { - Major companies such as Ernst \& Young and DLT ledger already in Kerala } \\
\text { could grow in the future and many work opportunities related to blockchain and } \\
\text { IT could be on their way to India. } \\
\text { - Like multinationals investing, they are building their own blockchain. A 2-year- } \\
\text { old Indian business Tech Mahindra is partnering with Dutch-based blockchain } \\
\text { technology incubator to build QUANTOZ to provide BaaS. } \\
\text { - Multinationals demonstrate an interest in Indian blockchain firms. Binance } \\
\text { acquired a crypto exchange network located in Mumbai-Wazir X for 10-15 } \\
\text { million } \\
\text { According to the World Intellectual Property Organization, India is sixth on the } \\
\text { blockchain space patent and development list, with a total of } 67 \text { patents accepted } \\
\text { in } 2018 \text {. }\end{array}$ \\
\hline Weakness & $\begin{array}{l}\text { - Encrypted data can be hacked / misrepresented from external sources. } \\
\text { - The picture of the blockchain regulations and their enforcement is still unclear. } \\
\text { The Indian government has yet to enforce clearly specified blockchain } \\
\text { technology regulations. } \\
\text { - Because of a lack of confidence and understanding, many supply chain vendors } \\
\text { are not willing to embrace blockchain technologies. } \\
\text { - If robust data validation is needed for blockchain (Proof-of -stake systems is } \\
\text { needed). }\end{array}$ \\
\hline
\end{tabular}




\begin{tabular}{|c|c|}
\hline $\begin{array}{l}\text { Opportunities } \\
\text { [17] }\end{array}$ & $\begin{array}{l}\text { - Post-demonetization, India has developed a progressive digitization outlook and } \\
\text { is aware of the benefits offered by blockchain and its potential for good } \\
\text { governance. } \\
\text { The blockchain initiatives of the Indian government are clearly noticeable } \\
\text { through the display of several proofs of concept (PoC) displayed in the finance, } \\
\text { land registry and insurance sectors. } \\
\text { - The Institute for Banking Technology Development and Research (IDRBT), the } \\
\text { RBI technology arm, ran two PoCs - a letter of credit to domestic trade finance } \\
\text { and enhanced payment information - including technology firms and banks like } \\
\text { IBM and Infosys. } \\
\text { The first state to implement blockchain for land records in Andhra Pradesh. } \\
\text { Also, the first state for implementing BC Centre \& other states like Karnataka, } \\
\text { Maharashtra, Kerala \& Rajasthan take a lead. } \\
\text { - Several other Indian business players have also been early adopters, exploring } \\
\text { trendscross-border payments, Trade finance supply chain management, loyalty } \\
\text { programs\& Digital identity. They have faced a fair share of obstacles before } \\
\text { they hit the use stage of the PoC test. }\end{array}$ \\
\hline $\begin{array}{l}\text { Challenges } \\
{[17,18]}\end{array}$ & $\begin{array}{l}\text { - Blockchain awareness is very minimal and shrouded in unregulated } \\
\text { cryptocurrency industry disrepute. Businesses interested in the blockchain may } \\
\text { be able to set aside an internal team focused on understanding the technology, } \\
\text { its impact and the usage areas. } \\
\text { Blockchain is seen as a complete platform replacing current technologies. This } \\
\text { confusion was also an impediment to its adoption. People need to understand } \\
\text { that blockchain is a tech component that will be integrated into the existing } \\
\text { system to allow business applications and new approaches. A professional } \\
\text { services company has developed a miniature blockchain framework model to } \\
\text { show a blockchain practical and tangible manner. } \\
\text { - Financial systems focused on the blockchain are being worked on. Many Indian } \\
\text { banks have started integrating the technology of blockchain within their banking } \\
\text { system. Yet another problem is the lack of oversight and a specific regulatory } \\
\text { body to bring about standardization and acceptance for mainstream adoption. } \\
\text { A further complication is the convergence of the latest blockchain technologies } \\
\text { and data protection during early stage growth. } \\
\text { The ban on crypto-currency in India adds to all of this. Indian blockchain } \\
\text { companies raise their funds rather than through the conventional funding } \\
\text { process through ICO (initial coin offering). They have been adversely affected } \\
\text { by the ban on cryptocurrencies and now start-ups try to collect funding outside } \\
\text { India. }\end{array}$ \\
\hline
\end{tabular}

\section{FINDINGS :}

1. Indian RBI has named numerous committees that work on BCT \& DLT.

2. Regulatory and legal changes are necessary if the digital finance industry is to grow sustainably for the future.

3. We can see the value in doing research on DLT / BCT in RBI's monthly and quarterly reports with an intention to introduce it in future days.
4. With different countries, central banks doing pilots on blockchain India are still in the stunted pilot stage.

5. India's supreme court ruled to introduce BCT and legalize cryptocurrencies for India's way forward.

6. BC being the latest topic, the expertise and ability in the masses are less likely to contribute to a shortage of qualified human resources. 
7. A more comprehensive understanding of risk inherent in the fintech platform has to be developed.

8. Together with RBI, IDRBT's is well positioned to build and maintain regulatory sandboxes allow to innovate and experiment with banking / payment resolutionsto the ultimateimplementation.

9. The nation needs to have stand-alone data protection and privacy rule.

\section{CONCLUSION :}

Distributed ledger technology and blockchain have grown considerably in functionality and sophistication over the span of a decade to provide solutions for various industries including the financial sector. Initially, computer scientists and few other interested individuals were limited to understanding the Distributed ledger technology because of their sophistication. However, there's widespread interest in Distributed ledger technology with applications in finance and other fields. Some central banks have conducted pilot projects in partnership with other institutions to research \& to know Distributed ledger technology,and discover possible aidsin their actions\& monetary systems. So far, several companies have theoretical characteristics to investigate the feasibility of making inter-bank transactions, digital assets, and tokens across border payments across distributed technology networks in leads with proven network capabilities. It should be noted that most of these central banks have not yet expressed the intention to build applications based on Distributed Ledger technology. In the case of CBDC, too,however, with its consequential advantages, these projects add to the capacity of central banks and regulators to accelerate the development of Distributed Ledger Technology's financial markets. It assists central banks in offering positive guidance when starting up new companies and organizations.

\section{REFERENCES:}

[1]

https://www.google.com/url?sa=t\&source=web \&cd=3\&ved=2ahUKEwjR7ei51YPpAhX0 XMBHdLzCysQFjACegQIARAB\&url=https\% 3A\%2F\%2Frbidocs.rbi.org.in\%2Frdocs\%2FPub
licationReport\%2FPdfs\%2FWGFR68AA1890D 7334D8F8F72CC2399A27F4A.PDF\&usg=AOv Vaw0iFeT4GeSEwkTbSRsV5Znx retrieved on April 10, 2020.

[2]

https://rbidocs.rbi.org.in/rdocs/Bulletin/PDFs/03 AR 11022020510886F328EB418FB8013 FBB684 BB5BC.PDFretrieved on April 08 2020.

[3] Raskin, M., \& Yermack, D. (2018). Digital currencies, decentralized ledgers and the future of central banking. In Research Handbook on Central Banking. Edward Elgar Publishing.118. https://www.nber.org/papers/w22238.pdf.

[4] Ølnes, S., Ubacht, J., \& Janssen, M. (2017). Blockchain in government: Benefits and implications of distributed ledger technology for information sharing.Government Information Quarterly, 34, 355-364.

[5] Smets, J. (2016, December). Fintech and central banks. In Conferenciaen el Colloquium of the Belgian Financial Forum encooperación con SUERF, el European Money and Finance Forum

Eggsplore.https://www.financialforum.be/sites/fi nancialforum.be/files/media/1695-1-jansmets.pdf.

[6] Bech, M. L., \& Garratt, R. (2017). Central bank cryptocurrencies. BIS Quarterly Review.9.55-70.

[7] Mills, D. C., Wang, K., Malone, B., Ravi, A., Marquardt, J., Badev, A. I., ... \&Ellithorpe, M. (2016). Distributed ledger technology in payments, clearing, and settlement.NMIMS Management Review,36(2), 60-89.

[8] Guo, Y., \& Liang, C. (2016). Blockchain application and outlook in the banking industry. Financial Innovation, 2(24). 1-12. DOI: https://doi.org/10.1186/s40854-016-0034-9.

[9] Gupta, A., \& Gupta, S. (2018). Blockchain technology application in Indian Banking Sector. Delhi Business Review, 19(2), 75-84.

[10] Kshetri, N., \&Kshetri, N. (2018). The Indian blockchain landscape: Regulations and policy measures. Asian Res. Policy, 9(2), 56-71. 
[11] Aithal, P. S. (2017). Industry Analysis The First Step in Business Management Scholarly Research. International Journal of Case Studies in Business, IT and Education (IJCSBE), 2(1), 1- $13 . \quad$ DOI: http://dx.doi.org/10.5281/zenodo.810347.

[12] http://www.idrbtca.org.in/Retrieved on $\underline{14 / 04 / 2020 .}$.

\section{[13]}

https://www.idrbt.ac.in/assets/publications/News letters/2017/NL_Jul2017.pdfRetrieved on $\underline{12 / 04 / 2020 .}$

[14] Aithal, P. S. \& Suresh Kumar, P. M. (2015). Applying SWOC Analysis to an Institution of Higher Education. International Journal of Management, IT and Engineering (IJMIE), 5(7), 231-247, DOI: http://doi.org/10.5281/zenodo.163425.

[15] Bhuvana R., Madhushree L. M.\&Aithal, P. A Review based Analysis on Current Implementations. International Journal of Applied Engineering and Management Letters (IJAEML), 4(1), 142155.DOI:http://doi.org/10.5281/zenodo.3822463

[16] Bhuvana R., \& Aithal, P. S. (2020). Blockchain based Service: A Case Study on IBM Blockchain Services \& Hyperledger Fabric. International Journal of Case Studies in Business, IT, and Education (IJCSBE), 4(1), 94-102.DOI:

http://doi.org/10.5281/zenodo.3822411.

[17]

https://www2.deloitte.com/content/dam/Deloitte /in/Documents/strategy/in-strategy-innovationblockchain-technology-india-opportunitieschallenges-noexp.pdfRetrieved on 18/04/2020.

[18] https://niti.gov.in/sites/default/files/202001/Bloc kchain_The_India_Strategy_Part_I.pdf

Retrieved on 20/04/2020

$* * * * * * * * * * * * *$ 